\title{
A produção política da economia: formas não-mercantis de acumulação e transmissão de riqueza numa sociedade colonial (Rio de Janeiro, 1650-1750)*
}

\section{Antônio Carlos Jucá de Sampaio}

Para analisarmos as formas não-mercantis de acumulação e transmissão de riqueza é preciso, antes de mais nada, distinguir claramente entre os diversos tipos de acumulação existentes. Foi Marx, indubitavelmente, quem melhor estabeleceu tais distinções:

Efetivamente, só na esfera da circulação simples, e sob a forma de entesouramento, se dá a acumulação da riqueza, ao passo que [...] as outras pretensas formas de acumulação só abusivamente são consideradas como tal, na medida em que se pensa sempre na acumulação simples do dinheiro [...]. Quem acumula carneiros torna-se pastor; a acumulação de escravos e de terras implica relações de domínio e escravatura etc. A formação de reservas de riquezas particulares exige processos particulares, diferentes do simples ato de acumulação, e desenvolve aspectos particulares do indivíduo. ${ }^{1}$

Considerando-se que a preocupação de Marx nesta passagem do texto era com o entesouramento do dinheiro, devemos ter cuidado ao transpor tal análise para um processo específico de acumulação. Mesmo assim, parece-nos importante a distinção entre uma acumulação de caráter mais geral e que se dá na esfera da circulação; e outra, vinculada à utilização de valores de uso e a processos particulares de formação da riqueza. Caso aprofundemos ainda mais nossa análise, veremos que se trata da diferença entre a acumulação de capital propriamente dita e uma acumulação de riqueza no seu sentido mais geral.

*Artigo recebido em fevereiro de 2003 e aprovado em junho de 2003. 
Por definição, o que diferencia o capital do dinheiro puro e simples é sua função na circulação. Na circulação simples de mercadorias, $\mathrm{M}-\mathrm{D}$ $\mathrm{M}$, a venda inicial é feita para se adquirir dinheiro com o qual se compra outra mercadoria. É o caso do agricultor que vende parte de seus produtos para adquirir aqueles que não produz. Ou seja, vende para comprar. Ao lado desta circulação temos outra bem diversa, D-M - D. Dinheiro que é convertido em mercadoria e posteriormente reconvertido em dinheiro. $\mathrm{Ou}$, na fórmula simples de Marx, comprar para vender. Obviamente, a única razão para esta aplicação do dinheiro é a possibilidade de ganho com a diferença entre preço de compra e preço de venda.

É evidente que a circulação D - M - D seria absurda e sem sentido, se o objetivo dela fosse o de permutar duas quantias iguais. [...]. O comerciante pode ter vendido por 110 libras ou por 100 o algodão comprado a 100, ou ser forçado a desfazer-se dele por 50 , mas de qualquer modo, seu dinheiro descreveu um movimento característico e original, muito diferente do que efetua na circulação simples [...]..$^{2}$

Portanto, só há capital e, conseqüentemente, sua acumulação, quando o dinheiro circula com a finalidade de produzir mais dinheiro. Nas sociedades capitalistas, esta circulação verifica-se em diversas atividades. Tal ocorre, por exemplo, na produção industrial. O capitalista, ao adquirir matéria-prima e mão-de-obra, busca produzir mercadorias que terão um valor superior ao dos fatores adquiridos. É exatamente na diferença do valor produzido por seus operários e do valor pago por este mesmo trabalho que reside a teoria da mais-valia de Marx. Para ele, o conceito de capital (e, portanto, sua acumulação) refere-se a realidades históricas bastante específicas, o que o levou a constantes ataques àqueles que percebiam a presença do capital em qualquer lugar e época ${ }^{3}$.

Fernand Braudel, por sua vez, embora não desenvolva a distinção entre as diversas formas de acumulação, ressalta as características dos investimentos em sociedades pré-capitalistas, os quais não buscavam garantir uma acumulação contínua para seu dono, e sim lhe garantir prestígio social, reproduzindo a hierarquia social preexistente:

"É certo que o dinheiro, nos campos, é raramente um verdadeiro capital: é empregado nas compras de terras e, através dessas compras, visa à promo- 
ção social - mais ainda, é entesourado: pensemos nas moedas dos colares femininos da Europa Central, nos cálices e patenas dos ourives de aldeia da Hungria, nas cruzes de ouro das camponesas da França nas vésperas da Revolução Francesa."

De fato, a acumulação de capital nas sociedades pré-capitalistas confunde-se totalmente, ou quase, com a atividade mercantil em seu sentido mais estrito, na qual verifica-se o movimento descrito por Marx. A produção de capital depende, assim, da apropriação de parte do sobretrabalho produzido através da circulação. Naturalmente, uma parcela desse mesmo sobretrabalho fica com a elite não-mercantil. No caso da sociedade escravista brasileira, é evidente que os senhores apropriam-se de uma parcela considerável do excedente produzido pelo suor de seus escravos. Entretanto, esta apropriação não tem como destino, ao menos de forma fundamental, a reprodução ampliada deste mesmo sobretrabalho. Sua principal função é garantir a própria manutenção do papel social desta elite e, com este, da estrutura social por ela controlada. Esse mesmo caráter conservador verifica-se na acumulação ocorrida em grupos sociais subalternos, como o campesinato.

Portanto, a distinção entre dois tipos de acumulação visa somente a facilitar nossa compreensão dos processos ocorridos na economia colonial. Não significa o estabelecimento de qualquer tipo de dicotomia entre ambas, como se disputassem fronteiras numa luta contínua. Na verdade, o que a pesquisa histórica tem mostrado é que as duas formas de acumulação freqüentemente se combinavam. Se tomarmos o trabalho de João Fragoso e Manolo Florentino, ${ }^{5}$ veremos que o grande comerciante que investe seu capital acumulado na agricultura transforma-o em riqueza nãocapitalizada, cuja função não é mais a de se reproduzir, mas a de "produzir" o seu dono, transformá-lo em membro da elite colonial. Além disso, tal transformação é muitas vezes facilitada pela concessão, por exemplo, de sesmarias, também esta uma forma de acumulação não-mercantil.

Estudos sobre tais formas de acumulação ainda são pouco comuns no Brasil. Segundo parece-nos, é em relação ao campesinato que eles se encontram mais bem desenvolvidos. ${ }^{6}$ Tratam-se, porém, de trabalhos voltados para o estudo de grupos ou tipos de produção específicos. As exceções são dois artigos recentes de João Fragoso, relativos à economia fluminense 
no século XVII, no qual aponta diversos mecanismos de acumulação nãomercantil de sua elite, como a ocupação de cargos na "República". 7 Poderíamos dizer também que diversas obras relativas ao período escravista referem-se a tais mecanismos. ${ }^{8}$ No entanto, faltam ainda análises que busquem aquilatar o papel deste tipo de acumulação na reprodução do conjunto da sociedade.

No Brasil colonial, a indistinção entre esferas da vida social e, conseqüentemente, das diversas formas de acumulação, também se fazia clara. Em parte, porque um bom pedaço da reprodução econômica dava-se fora do mercado, através de mecanismos como a apropriação de terras, o aprisionamento de índios, a ocupação de cargos públicos etc. E, por outra parte, porque mesmo nas relações ditas "de mercado" não cessavam de interferir relações sociais mais amplas, como as políticas e familiares, entre outras. $\mathrm{O}$ que torna bem pouco útil o estudo dos fenômenos econômicos de forma isolada, sem que se busque inseri-los no contexto social em que se moviam.

Foi exatamente por acreditarmos na importância de tais mecanismos de reprodução social existentes fora do mercado que planejamos este artigo. Com ele buscamos atingir dois objetivos: o primeiro, mais geral, é contribuir para o estudo das formas não-mercantis de reprodução social na sociedade colonial. O segundo, mais específico, é analisar a importância de tais mecanismos para o estudo da sociedade fluminense num período em que a mesma passou por importantes transformações. Tentamos assim perceber como tais transformações influenciaram nas estratégias de acumulação de riqueza.

Para iniciarmos o nosso estudo, analisamos as diversas formas de aquisição das propriedades rurais e urbanas ao longo do período, com a finalidade de aquilatarmos o peso relativo do mercado e de outros mecanismos de aquisição/acumulação. Para alcançar tal intento, analisamos as escrituras públicas de compra e venda, única documentação existente para o nosso período a abranger um número elevado de propriedades. Na verdade, buscamos olhar "através" das escrituras, levantando as formas através das quais os vendedores aí presentes haviam adquirido as propriedades então transacionadas. 


\section{TABELA 1: Formas de aquisição das propriedades rurais vendidas (1650-1750)}

\begin{tabular}{|c|c|c|c|c|c|c|c|c|c|c|c|c|}
\hline & \multicolumn{2}{|c|}{$1650-1670$} & \multicolumn{2}{|c|}{$1671-1690$} & \multicolumn{2}{|c|}{$1691-1700$} & \multicolumn{2}{|c|}{$1711-1730$} & \multicolumn{2}{|c|}{$1731-1740$} & \multicolumn{2}{|c|}{$1741-1750$} \\
\hline $\begin{array}{l}\text { Formas de } \\
\text { aquisição }\end{array}$ & $\mathrm{N}$ & $\%$ & $\mathrm{~N}$ & $\%$ & $\mathrm{~N}$ & $\%$ & $\mathrm{~N}$ & $\%$ & $\mathrm{~N}$ & $\%$ & $\mathrm{~N}$ & $\%$ \\
\hline $\begin{array}{l}\text { Arrematação/ } \\
\text { compra }\end{array}$ & 21 & 42 & 19 & 48,7 & 29 & 45,3 & 34 & 34,7 & 44 & 51,2 & 71 & 46,1 \\
\hline Herança & 23 & 46 & 13 & 33,3 & 29 & 45,3 & 47 & 48,0 & 30 & 34,9 & 55 & 35,7 \\
\hline Dote & 4 & 8 & 4 & 10,3 & 4 & 6,3 & 7 & 7,1 & 4 & 4,7 & 12 & 7,8 \\
\hline Doação & 0 & 0 & 1 & 2,6 & 2 & 3,1 & 4 & 4,1 & 2 & 2,3 & 3 & 1,9 \\
\hline Sesmaria & 1 & 2 & 1 & 2,6 & 0 & 0 & 3 & 3,1 & 2 & 2,3 & 5 & 3,3 \\
\hline Outros ${ }^{1}$ & 1 & 2 & 1 & 2,6 & 0 & 0 & 3 & 3,1 & 4 & 4,6 & 8 & 5,2 \\
\hline Total 2 & 50 & 100 & 39 & 100 & 64 & 100 & 98 & 100 & 86 & 100 & 154 & 100 \\
\hline
\end{tabular}

Fontes: Escrituras públicas dos cartórios do Primeiro e Segundo Oficios de Notas do Rio de Janeiro (1650-1750).

OBS.: 1- Nessa rubrica entram principalmente as formas mistas de aquisiçāo, ou seja, quando a propriedade foi adquirida, por exemplo, parte por herança e parte por compra; 2-A soma dos percentuais parciais pode ser diferente de 100 por conta dos arredondamentos realizados.

\section{TABELA 2: Formas de aquisição das propriedades urbanas vendidas (1650-1750)}

\begin{tabular}{|c|c|c|c|c|c|c|c|c|c|c|c|c|}
\hline \multirow[b]{2}{*}{$\begin{array}{l}\text { Formas de } \\
\text { aquisição }\end{array}$} & \multicolumn{2}{|c|}{$1650-1670$} & \multicolumn{2}{|c|}{$1671-1690$} & \multicolumn{2}{|c|}{$1691-1700$} & \multicolumn{2}{|c|}{$1711-1730$} & \multicolumn{2}{|c|}{$1731-1740$} & \multicolumn{2}{|c|}{$1741-1750$} \\
\hline & $\mathrm{N}$ & $\%$ & $\mathrm{~N}$ & $\%$ & $\mathrm{~N}$ & $\%$ & $\mathrm{~N}$ & $\%$ & $\mathrm{~N}$ & $\%$ & $\mathrm{~N}$ & $\%$ \\
\hline $\begin{array}{l}\text { Arrematação/ } \\
\text { compra }\end{array}$ & 21 & 47,7 & 19 & 38,0 & 16 & 51,6 & 50 & 61,7 & 57 & 69,5 & 92 & 57,9 \\
\hline $\begin{array}{l}\text { Herança/ } \\
\text { legado }^{1}\end{array}$ & 15 & 34,1 & 19 & 38,0 & 12 & 38,7 & 21 & 25,9 & 18 & 22 & 41 & 25,8 \\
\hline Dote & 8 & 18,2 & 6 & 12,0 & 0 & 0 & 1 & 1,2 & 4 & 4,9 & 11 & 6,9 \\
\hline Doação & 0 & 0 & 4 & 8,0 & 3 & 9,7 & 4 & 4,9 & 0 & 0 & 4 & 2,5 \\
\hline Sesmaria & 0 & 0 & 1 & 2,0 & 0 & 0 & 0 & 0 & 0 & 0 & 0 & 0,0 \\
\hline Outros & 0 & 0 & 1 & 2,0 & 0 & 0 & 5 & 6,2 & 3 & 3,7 & 11 & 6,9 \\
\hline Total 2 & 44 & 100 & 50 & 100 & 31 & 100 & 81 & 100 & 82 & 100 & 159 & 100 \\
\hline
\end{tabular}

Fontes: Escrituras públicas dos cartórios do Primeiro e Segundo Oficios de Notas do Rio de Janeiro (1650-1750). 
OBS.: 1- Encontramos somente duas aquisições por legado, ambas na década de 1730; 2-A soma dos percentuais parciais pode ser diferente de 100 por conta dos arredondamentos realizados.

Iniciemos nossa análise pelos dados relativos às formas de acesso às propriedades rurais. Em primeiro lugar, evidencia-se a importância das aquisições por arrematação ou compra. No quadro colonial fluminense, essas eram as formas possíveis de acesso à propriedade através do mercado. No entanto, embora tenham quase sempre apresentado os maiores percentuais em relação às demais, tais transações não chegavam a ser maioria entre as diversas maneiras possíveis de transmissão das propriedades rurais, com exceção da década de 1730. Mais ainda, é forçoso reconhecer que as profundas transformações ocorridas na economia fluminense na virada do século XVII não parecem ter exercido uma grande influência sobre a proporção entre as propriedades adquiridas através do mercado e as demais. Se tomarmos a segunda metade dos seiscentos e a primeira dos setecentos como dois períodos isolados, veremos que a variação entre ambas é praticamente nula: no primeiro período, as aquisiçōes por arrematação ou compra responderam por $45,1 \%$ do total, e no segundo por $44,1 \%$. Fenômenos como a maior monetarização da economia fluminense, seu novo papel no quadro do império português e o surgimento de uma elite mercantil claramente diferenciada da elite agrária modificaram muito pouco a forma como as propriedades rurais eram adquiridas. ${ }^{\text {? }}$

Essa constância torna-se mais clara quando percebemos que também entre as outras formas de aquisição as mudanças ocorridas são relativamente poucas ao longo do período analisado. Com exceção das propriedades adquiridas por sesmarias e da rubrica "outros", que tendem a aumentar sua participação a longo prazo, todas as demais (as mais importantes) mantêm, em linhas gerais, uma participação constante entre 1650 e 1750 . Sobretudo chamam a atenção, por sua importância, as aquisições havidas por meio de herança. Estas parecem quase uma imagem espelhada das aquisiçōes por arrematação ou compra: quando a participação de uma delas sobe, a da outra tende a cair. É real que, a partir da década de 1730 , verifica-se uma queda da participação das propriedades herdadas em relação ao total, mas somente uma análise que avançasse pela segunda metade dos se- 
tecentos poderia nos dizer se esta é uma transformação definitiva ou uma simples conjuntura. Seja como for, até a última década de nossa amostra as aquisiçōes por herança representavam pelo menos $1 / 3$ do total das propriedades vendidas, uma porcentagem bastante considerável.

Esses dados nos apresentam uma realidade surpreendente, e que, por isso mesmo, merece ser analisada com vagar. A primeira surpresa é com a ausência quase absoluta da posse como forma de aquisição das propriedades vendidas. De fato, encontramos somente uma escritura para todo o nosso período em que o vendedor declarava ter adquirido a propriedade transacionada por esse meio. ${ }^{10}$ Também nos inventários dos réus da inquisição não nos deparamos com qualquer referência a essa modalidade de aquisição de propriedades. Da mesma forma, Edval de Souza Barros, trabalhando com a documentação relativa a um levantamento dos títulos de propriedade, levado a cabo pelo Marquês do Lavradio em 1771, mostra que para as propriedades adquiridas no período 1721-1750 não há qualquer referência à aquisição de terras por esse meio. ${ }^{11}$

Encontramo-nos, assim, numa situação curiosa. A ausência nesse período da referência à posse como forma de acesso à terra coloca-nos em franca oposição ao quadro existente para o já bem estudado século XIX. Como apontam os diversos trabalhos existentes para esse último período, a posse era uma das formas mais usuais de aquisição e expansão das propriedades fundiárias. Segundo Hebe Mattos, tornou-se inclusive a principal a partir do fim das concessóes de sesmarias, em 1822, até a promulgação da lei de terras, em $1850 .^{12}$

Para o período colonial, há uma séria lacuna no que se refere ao estudo desse tema. Mesmo assim, os raros trabalhos existentes apontam para uma presença importante da posse como mecanismo de acesso à terra. É o caso, por exemplo, de Minas Gerais no século XVIII, estudado por Angelo Carrara. Trabalhando com as petiçôes de sesmarias, Carrara chega à conclusão de que a posse era a forma mais usual de aquisição de terras nos setecentos mineiros. Tal fato era em grande parte explicado, ou ao menos reforçado, pelo fato de o sistema agrário mineiro (e, por extensão, brasileiro) demandar a colonização constante de novas áreas, fazendo com que a ocupação das regiōes de fronteira se tornasse uma alternativa viável aos desprovidos de terra em suas regiôes de origem. ${ }^{13}$ 
Analisando os dados de uma relação de moradores da então capitania do Rio Grande de São Pedro de 1784, Helen Osório demonstrou que, naquele ano, 15\% do total de proprietários gaúchos haviam adquirido suas terras através da simples posse. Entretanto, ao analisar a forma como as terras da capitania tinham sido apropriadas pela primeira vez, esse índice chega a $41 \%$ do total, apresentando uma clara redução do acesso por posse entre os dois momentos. A causa disso é a consolidação do processo de colonização da capitania, embora no final do século XVIII a fronteira agrária ainda estivesse em plena expansão. ${ }^{14}$

Seria o Rio de Janeiro dos séculos XVII e XVIII uma notável exceção a esse quadro? Certamente não, sobretudo se levarmos em conta o fato de que a fronteira agrícola da capitania apresentava-se ainda aberta nesse período. ${ }^{15}$ A razão do silêncio, a nosso ver, está no "costume do Brasil" de se fazerem escrituras particulares de compra e venda, inclusive para valores superiores aos permitidos nas ordenaçôes filipinas. ${ }^{16}$

O mais provável é que as propriedades havidas por posse fossem transacionadas principalmente através de tais instrumentos, dada a ausência de um título legal de propriedade. Também é possível que boa parte das transações levantadas em que não há qualquer informação relativa à forma de aquisição refiram-se a posses. Nesse caso, o silêncio estaria ligado à inexistência pura e simples de qualquer espécie de titulação da propriedade em questão ${ }^{17}$. Tudo isso reforça a idéia de uma importância relativa do mercado no interior da sociedade colonial. Mais ainda, deixa claro que as escrituras públicas com que trabalhamos mostram-nos necessariamente uma imagem parcial desse mesmo mercado.

Igualmente curiosa é a presença bastante reduzida das sesmarias no conjunto das propriedades vendidas. Mesmo que não tenhamos dúvidas de que a participação destas no total das formas de aquisição nunca tenha sido majoritária (salvo talvez no início da colonização de cada região), seu papel marginal em nossa amostra exige uma explicação cuidadosa.

À primeira vista, podemos creditar esse fenômeno à própria característica do processo de colonização da América Portuguesa. Conforme apontou Francisco Carlos Teixeira,

[...] a ocupação do solo, ou ao menos a criação de uma malha fundiária inicial, parece ter acontecido independentemente do crescimento demográfi- 
co e da pressão daí decorrente. Ou seja, constituiu-se precocemente um processo de apropriação da terra, distinto de um processo de povoamento. ${ }^{18}$

A principal conseqüência dessa apropriação precoce do solo era a tendência das sesmarias possuírem uma importância máxima nos momentos iniciais de ocupação de novas regiôes, perdendo paulatinamente a partir daí seu papel no sistema agrário. Quando o processo de expansão da fronteira arrefecia, arrefecia igualmente a concessão de sesmarias. Além disso, boa parte destas era posta à venda logo após sua aquisição, o que contribuía para reduzir sua importância no sistema agrário.

Isso fica evidente na análise da evolução agrária da capitania do Rio Grande nos setecentos. Os dados da relação de 1784 mostram que, se num primeiro momento nada menos que $59 \%$ das terras haviam sido apropriadas através de sesmarias e outras formas específicas de doações governamentais, quando a relação é feita o índice de propriedades assim adquiridas já havia caído para menos de 1/3 do total. Por outro lado, em 1784 as propriedades havidas por compra, arrematação ou arrendamento já representavam $34,8 \%$ do total. É a própria autora quem ressalta o caráter especulativo de muitas das concessões de sesmarias que eram vendidas pouco depois de sua aquisição. Essas transformações ocorrem de forma bastante rápida, sobretudo se considerarmos que a ocupação efetiva da capitania não completara então meio século. ${ }^{19}$

No Rio de Janeiro não era diferente. Se retornarmos à tabela 1 veremos que, embora sempre muito reduzida, a participação das aquisições por sesmarias tende a crescer no século XVIII, em comparação com a segunda metade dos seiscentos. Em números, essa participação passa de 1,31\% do total para $2,96 \%$, refletindo a expansão da fronteira agrária, ocasionada pela ocupação de novas terras, notadamente o Caminho Novo.

Portanto, parece-nos correto afirmar que essa pequena presença das sesmarias está vinculada ao fato de que a ocupação da capitania fluminense começara quase cem anos antes do marco inicial de nosso estudo. Isso fazia com que tivesse se constituído então não somente um mercado de bens rústicos como também outras formas de acesso aos mesmos.

Mas isso explica apenas em parte os índices tão reduzidos das sesmarias no conjunto das propriedades transacionadas. É importante lembrar 
igualmente que, embora a segunda metade do século XVII não se caracterize por uma expansão notável da fronteira agrária fluminense, nem por isso as sesmarias deixaram de ser concedidas. Logo, há que se buscar outras causas para o fenômeno.

Uma delas era o fato de que boa parte das concessóes de sesmarias destinava-se a ordens religiosas que em geral optavam pela formação de imensos domínios, dos quais retiravam os recursos necessários ao seu sustento. ${ }^{20}$ Por isso mesmo, tais concessões só raramente retornavam ao mercado. Exemplos disso encontramos na análise das próprias escrituras de vendas rurais. Tomemos como exemplo os dois períodos extremos de nossa amostra, 1650-1670 e 1741-1750. Tanto num quanto noutro período não encontramos qualquer venda de propriedades rurais de ordens religiosas, trabalhando com amostras de 115 e 182 escrituras, respectivamente. Isso não significa que as instituições eclesiásticas não realizassem em absoluto vendas de partes de seus patrimônios, mas é um forte indicativo de sua resistência em fazê-lo. A principal conseqüência desse fenômeno era a exclusão do mercado de parte considerável dos bens agrários.

É também necessário lembrar que as sesmarias funcionavam preferencialmente como importantes mecanismos para a formação de patrimônios. Por isso mesmo, muitas delas tendiam a ser herdadas pelas famílias dos sesmeiros originais. Esses casos não são muito fáceis de serem detectados em nossa documentação. Mesmo assim, encontramos alguns exemplos, como o de Inácio de Proença Coutinho, que em 1746 vendeu terras que herdara do pai, coronel Bernardo Soares de Proença, o construtor da "variante do Proença” do Caminho Novo, e que em pagamento por seu serviço recebera diversas sesmarias na área que ajudou a desbravar. ${ }^{21}$

Na mesma década, D. Maria Batista de Jesus, viúva do Sargento-mor Lucas de Barros Paiva, vendeu terras que herdara do marido, e que este adquirira "por carta de sesmaria do governador Gomes Freire de Andrade". ${ }^{22}$ Também temos o exemplo da venda feita por Manuel de Barcelos Machado, sua mulher Maria Pimentel e a cunhada, Francisca Pimenta. As duas irmãs herdaram as terras vendidas de Margarida Ferreira, "que as houve de sua mãe, que as houve por sesmaria". ${ }^{23}$ Temos aqui propriedades que depois de adquiridas através de cartas de sesmarias foram herdadas por duas gerações, até serem postas no mercado. Assim, é provável que boa parte das 
propriedades que em nossa tabela aparecem como herdadas tenham sido apropriadas primariamente da mesma forma.

O dote, por sua vez, tem uma importância muito relativa entre as vias de aquisição de propriedades rurais, embora quase sempre seja a terceira forma mais comum, vindo atrás da aquisição através do mercado (arrematação ou compra) e da herança. De qualquer forma, é somente no período 1671-1690 que a aquisição por dote atinge o patamar de $10 \%$ do total.

Pode-se argumentar que essa fraca presença do dote estaria relacionada ao fato de que ele estava destinado à formação de patrimônios e era mais provável que fossem herdados pelos filhos dos dotados do que postos à venda no mercado. Para testar essa possibilidade, comparamos a proporção existente entre as vendas rurais e as escrituras de dote em cada período. Assim, para 1650-1670, por exemplo, temos 38 escrituras de dote para 115 vendas rurais. A proporção é de 3,03 vendas rurais para cada dote, menor do que a existente entre arrematação/compra e dote na tabela $1(5,25)$, o que aparentemente indicaria uma subestimação do dote em nossa amostra. Contudo, é importante lembrar que o dote não se referia somente a bens rurais, mas também aos urbanos e de outros tipos (escravos, móveis, jóias, etc.), como veremos abaixo. Assim, parece-nos que a tabela mostra com razoável confiabilidade o peso que o dote possuía entre as formas de acumulação de riqueza existentes na sociedade fluminense entre 1650 e 1750 .

Não nos parece exagerado afirmar que o dote estava longe de ser um elemento fundamental nas estratégias de acumulação, o que torna necessária a relativização de seu papel como mecanismo de contrapeso à tendência igualitária do sistema de herança português, idéia defendida por Carlos Bacellar. ${ }^{24}$ Fique claro que não se trata de negar seu papel, mas de reconhecer sua importância secundária diante de outras formas tanto de aquisição da propriedade quanto de partilha de heranças. Além disso, é provável que o dote possuísse peso específico variável conforme a região e período considerados. Como o próprio Bacellar demonstra, havia vários mecanismos para garantir que a transmissão de bens entre gerações não significasse necessariamente o desaparecimento das fortunas familiares. ${ }^{25}$

O próprio dote freqüentemente englobava em seu valor o pagamento de heranças. É o que ocorre com Joana Filgueira, que, ao se casar em 1661 com Luís Mendes, recebeu de sua mãe e de seu padrasto um dote 
que incluía duas casas, duas escravas, jóias e enxoval. $\mathrm{O}$ valor desses bens cobria não só o dote em si como o pagamento de sua legítima paterna. ${ }^{26}$

Essa não é uma característica exclusiva do seiscentos fluminense. No século seguinte permanece o hábito de se utilizar a concessão do dote como momento para o pagamento das heranças devidas, no todo ou em parte. Foi o que ocorreu, por exemplo, com Isabel Cabral de Mello, membro de uma família com diversos senhores de engenho. Ao se casar com Miguel de Barros Ramiro, em 1712, recebeu de sua mãe, Vitória Rodrigues Machado, um dote no valor de 1:600\$000, valor no qual estavam inclusos os $680 \$ 000$ que essa lhe devia de sua legítima paterna ${ }^{27}$. Esses exemplos, entre outros, mostram que o dote nem sempre se constituía numa simples antecipação de herança, mas podia confundir-se em parte com o pagamento da própria, o que reforça ainda mais a importância dos bens herdados na constituição dos patrimônios agrários.

As doações, por sua vez, apresentam uma importância sempre muito pequena entre as formas de acesso a propriedades rurais. Veremos mais adiante que a principal razão para isso estava na própria variedade dos bens doados, bem como das finalidades das doações. Por ora, o que nos interessa ressaltar é que essa pequena participação, somada à importância apenas relativa dos dotes, demonstra que a transmissão não-onerosa de bens agrários poucas vezes se dava entre indivíduos vivos. Muito mais freqüente é que essa transmissão ocorresse com a morte do possuidor original. De onde se conclui que o acesso a propriedades rurais, quando não ocorria através do mercado, dependia fundamentalmente das etapas da vida familiar.

Esse fato é demonstrado de forma clara por João Fragoso, no que se refere ao Rio de Janeiro seiscentista. Numa amostragem de 435 casos, ele encontrou uma idade média de casamento tardia para os homens: 29,7 anos. Ao calcular que os homens em média faleciam aos 59,3 anos, Fragoso conclui que

[...] a constituição de uma família nuclear ou, o que é o mesmo, a entrada em cena de uma nova geração, dependia dos recursos deixados pelo desaparecimento da geração anterior. ${ }^{28}$

Afirmar a importância das aquisições feitas fora do mercado não significa, naturalmente, negar a importância deste na constituição das fortu- 
nas fluminenses do período 1650-1750. Ele responde, em qualquer período, por algo em torno de um terço a metade das aquisições. Além disso, não é difícil imaginar que as heranças, dotes, doações e outras formas de aquisição levassem sempre em consideração na sua realização o valor de mercado dos bens assim transferidos, ainda que como simples referência. Com tudo isso, ainda se evidencia a força do setor não-mercantil na economia fluminense ao longo de todo o período 1650-1750. Sobretudo, chama a atenção o fato de que a expansão econômica ocasionada pela ocupação das regiōes auríferas não significou transformações consideráveis nesse quadro. Pelo contrário, a expansão do povoamento na capitania, sobretudo nos caminhos que demandavam as minas, estimularam antigas formas de apropriação da terra, notadamente o instituto da sesmaria.

A análise das formas de aquisição das propriedades urbanas vendidas, por sua vez, aponta para uma evolução distinta da encontrada no estudo das propriedades rurais, confirmando assim a importância do estudo em separado desses dois universos.

A principal diferença encontra-se no comportamento da participação das aquisições através do mercado em relação às demais. Ao contrário das propriedades rurais, em que essa via de acesso tende a se manter estável, no meio urbano há um considerável incremento. A esse respeito, convém ressaltar a semelhança entre as proporções em que tanto propriedades rurais quanto urbanas eram adquiridas por arrematação ou compra ao longo da segunda metade do século XVII. Em relação às primeiras, esse percentual era de $45,1 \%$, como vimos, enquanto para as últimas era de $44,8 \%$.

A transformação ocorrida nos setecentos é o reflexo inegável do dinamismo urbano gerado pela participação fundamental da urbe carioca nos eixos mercantis fundamentais do Império. ${ }^{29}$ A nosso ver, esse aumento das compras e arrematações sobre as demais formas de aquisição aponta para uma transformação dos bens urbanos em simples mercadorias, transacionadas com grande freqüência. Isso fica claro principalmente pela queda dos dotes e doações, o que mostra que a transmissão não-onerosa de tais bens perde grande parte de sua importância no seio das estratégias familiares de acumulação de riquezas.

Já a queda na proporção de bens herdados demonstra uma volatilidade maior na posse de bens urbanos. Qualquer bem, urbano ou rural, é herda- 
do em algum momento de sua existência, ou seja, passado de algum proprietário para o(s) seu(s) herdeiro(s). Logo, um aumento da proporção de compras/vendas sobre as heranças aponta para uma circulação mais rápida desses bens, visto que há uma tendência menor de que a transmissão da propriedade dependa do ciclo de vida do proprietário.

Deve-se ainda levar em conta que outras formas de aquisição presentes na área rural encontravam-se virtualmente bloqueadas no espaço urbano, o que sem dúvida contribuía para a mercantilização das propriedades aí localizadas. O exemplo mais evidente é o da posse, tornada impossível pelo fato de que o interior da urbe carioca já se encontrava totalmente apropriado no período, sob diversos títulos. A mesma razão também impossibilitava a concessão de sesmarias, o que não impedia que essas continuassem sendo concedidas no entorno da área urbana.

É lógico que esse peso preponderante do mercado na aquisição dos bens urbanos vincula-se diretamente ao fortalecimento do capital mercantil no interior da sociedade fluminense desde o final do século XVII. ${ }^{30}$ Era no espaço urbano que o capital mercantil se reproduzia enquanto tal. A aquisição ou construção de lojas, armazéns, sobrados, trapiches etc., era parte fundamental da reprodução ampliada desse mesmo capital. Ao se utilizarem do mercado para as suas aquisições, os negociantes acabavam por ampliar o grau de mercantilização da sociedade urbana como um todo, internando aí os recursos adquiridos em seus negócios no império. Desta forma, o desenvolvimento da urbe carioca vai ser crescentemente condicionado pelos movimentos e tendências do setor mercantil.

Portanto, ao compararmos a evolução das formas de aquisição das propriedades rurais e urbanas ao longo do nosso período, veremos que elas apresentam trajetórias divergentes ao longo do século XVIII. Enquanto nos seiscentos ambos os tipos de propriedades estavam claramente inseridos em estratégias de acumulação de riquezas, o que condicionava em grande medida a sua transmissão, na primeira metade da centúria seguinte isso deixa de ser verdade para os bens urbanos, ainda que não para os rurais. Em outras palavras, a maior mercantilização dos bens urbanos transformou-os em instrumentos adequados para uma forma mais específica de acumulação, baseada na utilização desse mesmo mercado para garantir sua reprodução contínua: a acumulação de capital. 


\section{As formas de transmissão da riqueza}

Já vimos que os dotes e doações têm uma importância relativa entre as formas de aquisição de propriedades, sejam elas urbanas ou rurais. Mais ainda, ficou claro que a importância do dote como uma antecipação de herança e/ou mecanismo compensador da igualdade prevista no sistema português de herança é igualmente pequena em terras fluminenses. Mesmo assim, parece-nos de grande importância estudá-los, porque apesar de sua pequena participação no total, dotes e doações aparecem ao longo de todo o período, demonstrando sua inserção nas estratégias de reprodução e acumulação dos diversos grupos sociais fluminenses. Além disso, e o que nos parece ainda mais significativo, o estudo das características desses mecanismos de transmissão da riqueza nos fornece importantes informaçôes sobre a sociedade em que se encontravam inseridos, bem como sobre suas transformaçōes. ${ }^{31}$

Comecemos nossa análise pelo dote. Pelas tabelas 1 e 2 já havia ficado claro que sua importância tende a se reduzir ao longo do século XVIII, sobretudo no que se refere às propriedades urbanas, onde apresentava maior participação. Essa menor importância também fica clara pela diminuição de sua presença no total das escrituras. Tendo encontrado um total de 66 escrituras de dote para a segunda metade do século XVII, deparamo-nos tão-somente com 61 para a primeira metade da centúria seguinte. A queda pode parecer pequena em termos absolutos, mas deve-se considerar que contamos com um número muito maior de escrituras para o setecentos do que para o seiscentos, até porque trabalhamos com o material de dois ofícios de notas, enquanto para o período anterior contamos com dados de somente um deles. Se compararmos o número de escrituras de dote com os das relativas às vendas, essa decadência ficará mais clara. Já vimos anteriormente que no período 1650-1670, encontramos um total de 38 escrituras de dote e 115 de vendas rurais. Caso tomemos como contraponto a década de 1740, veremos que há somente 26 escrituras de dote, em contraposição a 182 escrituras de vendas rurais ${ }^{32}$. Não contamos com estudos sobre o comportamento do dote em outras regiōes que nos permitam verificar até que ponto o quadro observado na capitania fluminense repete-se (ou não) em outras áreas. 
Para entendermos melhor essa evolução do dote em solo fluminense é necessário que nos aprofundemos no estudo de sua composição, com a finalidade de compreendermos de que forma ele se encaixa nas estratégias de reprodução dos diversos grupos sociais.

\section{TABELA 3: Participação dos diversos itens nos dotes fluminenses (1650-1750)}

\begin{tabular}{|l|r|r|r|r|}
\hline \multirow{2}{*}{ Itens } & \multicolumn{2}{|c|}{$\mathbf{1 6 5 0 - 1 7 0 0}$} & \multicolumn{2}{c|}{$1711-1750$} \\
\hline & $\mathrm{N}$ & \multicolumn{1}{c|}{$\%$} & $\mathrm{~N}$ & \multicolumn{1}{c|}{$\%$} \\
\hline Escravo & 40 & 60,6 & 24 & 39,3 \\
Terras & 18 & 27,3 & 14 & 23,0 \\
Casa & 20 & 30,3 & 25 & 41,0 \\
Terreno & 9 & 13,6 & 3 & 4,9 \\
Dinheiro & 16 & 24,2 & 18 & 29,5 \\
Jóias & 15 & 22,7 & 12 & 19,7 \\
Açúcar & 12 & 18,2 & 0 & 0 \\
Enxoval 1 & 17 & 25,8 & 5 & 8,2 \\
Bens Móveis ${ }^{2}$ & 14 & 21,2 & 5 & 8,2 \\
\hline
\end{tabular}

Fontes: Escrituras públicas dos cartórios do Primeiro e Segundo Oficios de Notas do Rio de Janeiro (1650-1750).

OBS.: 1 - Inclui vestidos; 2- Inclui móveis e outros objetos, exceto os do enxoval.

\section{TABELA 4: Participação dos diversos tipos de dotes fluminenses, conforme sua composição (1650-1750)}

\begin{tabular}{|l|c|r|r|r|}
\hline Tipo de dote & \multicolumn{2}{|c|}{$\mathbf{1 6 5 0 - 1 7 0 0}$} & \multicolumn{2}{c|}{$\mathbf{1 7 1 1 - 1 7 5 0}$} \\
\hline & $\mathrm{N}$ & \multicolumn{1}{c|}{$\%$} & $\mathrm{~N}$ & \multicolumn{1}{c|}{$\%$} \\
\hline Dotes rurais & 16 & 24,2 & 15 & 24,6 \\
Dotes urbanos & 19 & 28,8 & 26 & 42,6 \\
D. urbanos/rurais & 11 & 16,7 & 1 & 1,6 \\
Outros 1 & 20 & 30,3 & 19 & 31,2 \\
Total & $\mathbf{6 6}$ & $\mathbf{1 0 0 , 0}$ & $\mathbf{6 1}$ & $\mathbf{1 0 0 , 0}$ \\
\hline
\end{tabular}


Fontes: Escrituras públicas dos cartórios do Primeiro e Segundo Ofícios de Notas do Rio de Janeiro (1650-1750).

OBS.: 1 - Engloba todos os dotes que não apresentavam em sua composição qualquer tipo de bem que pudesse ser definido como claramente urbano ou rural.

As tabelas demonstram que entre os dois períodos há modificações consideráveis na composição dos dotes fluminenses. Em qualquer um deles encontraremos grandes diferenças na comparação com os dotes paulistas estudados por Muriel Nazzari.

Cabe-nos primeiramente analisar a participação dos escravos, dada a sua importância para a economia colonial. Nos dotes eles desempenhavam um duplo papel: como mão-de-obra e como reserva de valor. No período 1650-1700, os escravos possuíam um peso considerável, compatível com sua importância na economia colonial. Nada menos de $60 \%$ dos dotes contavam com escravos em sua composição. No entanto, mesmo nesse período sua participação ainda era bem menos significativa do que a verificada em São Paulo. Segundo os dados de Nazzari, na capitania paulista os cativos estavam presentes em nada menos de $95 \%$ dos dotes do século XVII, e na centúria seguinte esse percentual permanecia ainda muito significativo (80\%). ${ }^{33}$ No caso fluminense, sua participação caiu significativamente durante a primeira metade dos setecentos, ficando os mesmos presentes em pouco menos de $40 \%$ dos dotes.

A explicação para a diferença existente entre Rio de Janeiro e São Paulo está nas próprias amostras trabalhadas, que representam universos bastante distintos. Em São Paulo os dotes apontam para uma sociedade essencialmente rural, como fica claro pela pequena presença das casas urbanas entre os objetos dotados (no século XVII, somente $8 \%$ dos dotes possuem casas em sua composição, número que baixa para $2 \%$ nos setecentos), como pela presença de animais e ferramentas agrícolas. ${ }^{34}$ Já no caso do Rio de Janeiro as residências urbanas são presença constante e crescente nos dotes, enquanto as menções a animais, por exemplo, são raras. Já as terras estão presentes em $45 \%$ dos dotes paulistas seiscentistas, enquanto nos fluminenses aparecem somente em aproximadamente $1 / 4$ do total.

Tudo isso aponta para um caráter bem mais urbanizado da sociedade fluminense ante a paulista. Não devemos, porém, exagerar essas diferen- 
ças. Sem dúvida, boa parte desse caráter urbano dos dotes fluminenses se deve às especificidades da amostra trabalhada. Os dois ofícios analisados situavam-se na cidade do Rio de Janeiro, o que sem dúvida influenciava as características dos dotes aí registrados. Se tivéssemos acesso às escrituras de outras regiōes da capitania, com certeza, o quadro resultante seria diferente. De qualquer forma, não devemos nos esquecer que os bens agrários marcavam significativa presença nas escrituras fluminenses. Além das terras, presentes na tabela 3, ocorriam dotações também de partidos de cana, ou de outras propriedades agrícolas já estruturadas, inclusive engenhos. ${ }^{35}$

A partir daí, podemos considerar que as escrituras fluminenses são representativas da realidade existente na área do entorno da Baía de Guanabara, que apresentava uma economia agrária bem desenvolvida, com grande produção de açúcar e um núcleo urbano já importante, ao menos em relação ao tamanho da economia local.

Por outro lado, ao analisarmos atentamente a tabela 4, vemos claramente que a participação dos bens rurais nos dotes fluminenses era bastante reduzida. Mesmo durante a segunda metade do século XVII, os dotes que não possuíam bens rurais em sua composição (definidos como "urbanos" e "outros") alcançavam ampla maioria em relação ao total. No período 1711-1750, esse quadro se agravou, devido sobretudo à decadência dos dotes mistos, que englobavam tanto bens rurais quanto urbanos, e que tenderam então a se tornar exclusivamente urbanos. Neste segundo momento, a participação dos dotes com bens rurais no total reduziu-se a aproximadamente 1/4. Esse fato nos explica por que os dotes possuíam uma participação tão reduzida entre as formas de aquisição das propriedades rurais, conforme apontado na tabela 1, e corrobora a fundamental importância da herança como via de constituição dos novos núcleos familiares, sobretudo ao longo dos seiscentos.

A pergunta que devemos nos fazer é: qual o papel desempenhado pelos dotes no interior da sociedade fluminense, pelo menos daquela que vivia no entorno da Baía de Guanabara? Trabalhando com os dotes paulistas seiscentistas, ${ }^{36}$ Nazzari não tem dúvidas em afirmar sua importância na própria constituição das novas unidades familiares. No século XVII, esses dotes destinavam-se a auxiliar a nova família na formação de sua unidade produtiva e por isso os bens dotados eram constituídos fundamentalmen- 
te de meios de produção. No século seguinte se iniciaria uma clara transformação na composição e na função do dote que passou a se destinar mais ao consumo do casal do que à atividade produtiva. Para Nazzari, isso refletia uma transformação do próprio papel da família que deixou de ser uma unidade de produção para transformar-se em unidade de consumo. Além disso, mostraria também "um declínio da ascendência da familia da noiva sobre as atividades produtivas do noivo". ${ }^{37}$ Parece questionável tirar conclusões tão gerais sobre a evolução das famílias paulistas da simples análise da composição dos dotes. De fato, entendemos que as transformações ocorridas refletem muito mais a crescente mercantilização da economia paulista, o que a tornaria menos dependente do dote (sobretudo no que se refere à sua elite) para garantir sua reprodução. ${ }^{38}$

O quadro no Rio de Janeiro, entretanto, era bastante distinto. A participação minoritária dos bens rurais nessa forma de transmissão da riqueza mostra que a constituição de novas unidades produtivas nunca foi sua principal função. Temos consciência de que mesmo nos espaços urbanos constituíam-se unidades produtivas, e entre os bens urbanos dotados poderia haver lojas, armazéns, oficinas etc. Contudo, não é isso que se verifica numa análise mais cuidadosa de nossa amostra. Nos dotes em que apareciam bens urbanos, esses eram quase invariavelmente casas e terrenos, sem qualquer menção a bens ligados a atividades produtivas, como ferramentas. ${ }^{39}$

Permanece, portanto, a dúvida sobre qual era a real função dos dotes fluminenses. Em termos econômicos, vemos que uma minoria deles pretendia, assim como nos dotes paulistas, fornecer ao novo casal os meios necessários para o estabelecimento de uma nova unidade produtiva, autônoma ou não em relação aos dotadores. É o caso dos engenhos dotados. No século XVII também era relativamente comum que os partidos de canas ${ }^{40}$ entrassem na composição dos dotes, aparecendo em nove deles (13,6\%). É um desses partidos que Diogo da Fonseca dá a seu genro, o sargento-mor Diogo Cardoso de Mesquita, em 1662. ${ }^{41}$ No século XVIII, os partidos deixam de aparecer nos dotes, o que comprova a decadência do setor açucareiro no interior do agro fluminense do período. Entretanto, ainda encontramos doações de propriedades agrícolas inteiras, como a que Mateus da Cunha doou em 1749 a seu genro, Caetano Lopes da Costa. 
Tratava-se de uma unidade produtora de alimentos (entre as benfeitorias consta uma "casa de fazer farinha"), com casa de vivenda e nove escravos, além de uma lancha de pesca. ${ }^{42} \mathrm{Na}$ maioria das vezes, os dotes que englobavam algum tipo de bem rural referiam-se somente à transferência de terras, sem quaisquer benfeitorias citadas.

Mesmo entre a elite agrária não era costume dotar as filhas com propriedades rurais. E é exatamente o comportamento desse grupo que nos mostra que a relativamente pequena participação dos bens rurais nos dotes fluminenses não reflete apenas um viés "urbano" da amostra, mas também alguns aspectos fundamentais da economia fluminense.

Exemplo disso encontramos no dote que Petronilha Fagundes, viúva de João Fagundes Paris e senhora de engenho, contrata com Manuel Teles Barreto, membro da casa dos Mariz, para que se case com sua filha, Isabel Fagundes. O dote estipulado no contrato tem valor elevado para a época (1:600\$000), mas é pago exclusivamente em escravos africanos (um bem bastante valorizado) e açúcar que, nas condições seiscentistas, fazia a vez de dinheiro. ${ }^{43}$ Portanto, o casamento de Teles Barreto não o transformou de imediato em senhor de engenho, pelo menos de direito. Mas é esse mesmo casamento que lhe permite, posteriormente, herdar o engenho de sua sogra. ${ }^{44}$

Na mesma década, Catarina da Fonseca, também viúva de senhor de engenho, concedeu para o casamento de sua filha, Isabel de Cerqueira, um dote do mesmo valor do de Isabel Fagundes e composto por açúcar, quatro escravos, móveis e tecidos. ${ }^{45}$ No final do mesmo século temos o senhor de engenho Francisco Dias Medonho e sua mulher dotando a filha e o genro com dinheiro, dois escravos e o enxoval. ${ }^{46}$

Também no século XVIII os membros da elite agrária poucas vezes optaram pela dotação de unidades produtivas completas. Em 1745, ao se casar em segundas núpcias com Dona Ana Maria de Souza Pereira, filha de Dona Andresa de Souza Pereira, o então capitão João Barbosa de Sá Freire (posteriormente, chegaria a mestre-de-campo), filho e neto de senhores de engenho, recebe como dote um sobrado na rua da Cruz sobre o qual pesava uma hipoteca, bem como as legítimas de outras filhas de Andresa, e mais dois escravos. ${ }^{47}$ Da mesma forma, ao casar sua filha com Custódio de Souza, Manuel Correia Vasques, que além de senhor de engenho era "fidalgo 
da casa de Sua Majestade" e membro de uma das mais tradicionais famílias cariocas, a dota com dinheiro, escravos e um terreno urbano, onde compromete-se a construir uma casa. ${ }^{48}$

Tais exemplos evidenciam que os dotes no Rio de Janeiro, salvo as exceções de praxe, não tinham como principal função a acumulação de bens patrimoniais e, menos ainda, a formação de novas unidades produtivas, dependentes ou não dos sogros. ${ }^{49}$ Economicamente, sua principal utilidade parece ter sido a de fornecer ao novo casal uma espécie de "capital inicial", a ser utilizado pelo genro na montagem dos negócios da nova unidade familiar. Esse caráter mais flexível dos dotes fluminenses ante os paulistas, já que menos ligados a atividades econômicas específicas, sobretudo a agricultura, vincula-se diretamente ao elevado grau de mercantilização da economia fluminense desde os seiscentos. Numa sociedade em que a atividade mercantil encontrava-se suficientemente desenvolvida para se apresentar como uma importante via de ascensão social, o cuidado em se dotar genros e filhas com unidades produtivas completas mostrava-se desnecessário ou mesmo contraproducente. Pelo contrário, dotes que contassem em sua composição com dinheiro, escravos, ou mesmo terras avulsas, mostravamse mais úteis aos dotados, pois permitia que pudessem dispor com mais facilidade de seus bens, e assim aproveitar melhor (ou defender-se) das diversas conjunturas econômicas. ${ }^{50}$ Não é à toa que praticamente $1 / 4$ de todos os dotes seiscentistas possuíam dinheiro em sua composição, sem contar os que incluíam açúcar. E isso num período em que, segundo todas as fontes, era aguda a carência de numerário na capitania.

O quadro torna-se ainda mais claro no século XVIII. O acelerado desenvolvimento da atividade mercantil do porto carioca refletiu-se nos dotes, não só com o aumento da proporção daqueles que contavam com dinheiro em sua composição, como também de um conjunto de bens facilmente transacionáveis, como casas e terras avulsas. ${ }^{51} \mathrm{~A}$ influência do desenvolvimento mercantil na composição desses dotes torna-se mais clara na década de 1740, quando encontramos algumas escrituras em que os dotadores eram homens de negócio. Destacamos duas, em que tanto os dotadores quanto os dotados eram negociantes.

Na primeira, Cosme Velho Pereira, negociante atuante no Rio desde pelo menos o início do século XVIII, dá a Custódio Rodrigues Bandeira 
um dote no valor total de 4:240\$000, sendo 4:000\$000 em dinheiro, e o resto em três escravas. Além disso, dota a filha com um enxoval e várias jóias, não avaliadas. ${ }^{52}$ Trata-se de um dote de valor bastante considerável, e que por sua composição praticamente só era acessível a um negociante. $\mathrm{O}$ segundo dote é o que João Lopes deu a Brás Gonçalves Portugal para casar-se com sua filha, Francisca Antônia de Assunção. O valor total do dote era de 6:400\$000, pagos integralmente em dinheiro. ${ }^{53}$

Os dois exemplos acima podem ser considerados como casos extremos de transformação do dote em capital. Neles, não há uma transferência de bens patrimoniais acumulados ao longo de uma ou mais geraçôes de uma mesma família, em benefício de um genro específico. Pelo contrário, estamos diante de uma autêntica transação mercantil, um verdadeiro "aporte de capital" ocorrido entre negociantes e que se mostrava interessante para ambos, já que significava a formação, ou consolidação, de uma sólida aliança entre os mesmos. Apesar de extremos, esses dois exemplos, se considerados em conjunto com a composição extremamente variável dos dotes fluminenses, reforçam a idéia de uma grande flexibilidade.

Mas o dote tinha também uma outra função: unir famílias. É aí que encontramos seu principal significado na sociedade fluminense. A concessão de dotes às filhas nubentes sinalizava de forma clara a capacidade econômica de uma dada família. A possibilidade de abrir mão de parte dos bens acumulados em benefício do novo casal era um importante indicador do nível de riqueza, e transformava a família que estivesse apta a isso em uma importante participante do mercado matrimonial local.

A principal função do dote parece ter sido a de definir as alianças matrimoniais mais interessantes, para cada família, casa senhorial ou grupo social em um dado momento. O dote aparecia, assim, como um identificador dos "iguais" no interior desse mercado. É claro que a igualdade aqui deve ser relativizada. Não significa, necessariamente, que os dotadores e o genro dotado fizessem parte necessariamente do mesmo grupo social, ou que tivessem o mesmo nível de fortuna, mas sim que a união se mostrava mutuamente vantajosa.

Mas havia outras formas de transferências não-onerosas intervivos. Elas também jogavam um papel significativo nas estratégias familiares de re- 
produção ou ampliação do status social. São elas as doações e os patrimônios dos eclesiásticos.

As doaçôes englobavam uma ampla gama de situações bastante distintas entre si. Elas podiam ser "puras e graciosas", quando não previam qualquer contrapartida, ou "gravosas", quando o doado era obrigado ao cumprimento de certas obrigações para fazer jus ao seu recebimento. Podia-se fazer, por exemplo, doaçôes a igrejas, irmandades ou ordens religiosas, em troca de um certo número de missas pela alma do doador. Dentro desse amplo leque de opções limitaremos nossa análise às doações intrafamiliares, nas quais é possível descortinar as estratégias de reprodução social dos diversos grupos coloniais.

Vemos que boa parte das doações guardava grande semelhança com os dotes. Embora não pudessem ser consideradas dotes no sentido estrito, pois não estavam ligadas a um contrato de casamento específico, as razões dos doadores eram muito explícitas nesses casos. É assim que Elena do Couto fez uma doação para sua neta homônima de uma casa de sobrado, com a intenção de ajudar no seu dote. ${ }^{54} \mathrm{O}$ mesmo motivo levou o frei Cosme de São Damião, do Convento de Santo Antônio, a doar 10 escravos angolanos para quatro sobrinhas. ${ }^{55}$

Outro fator que aproximava tais doações dos dotes é o fato de que, sobretudo nos seiscentos, boa parte delas eram destinadas aos genros. Por outro lado, a perda de importância desses como destinatários das doaçôes no século seguinte deixa bem claro que a decadência dos dotes não era um fato isolado. Pelo contrário, ela estava ligada a um fenômeno mais geral, a perda de importância dessas formas de transferências de riquezas como vias de acumulação. 


\section{TABELA 5: Destinatários das doações, conforme o laço de parentesco com os doadores $(1650-1750)$}

\begin{tabular}{|l|r|r|r|r|}
\hline Tipos de parentesco & \multicolumn{2}{|c|}{$1650-1700$} & \multicolumn{2}{|c|}{$1711-1750$} \\
\hline & $\mathrm{N}$ & \multicolumn{1}{c|}{$\%$} & $\mathrm{~N}$ & \multicolumn{1}{c|}{$\%$} \\
\hline Irmãos & 12 & 26,1 & 18 & 23,7 \\
Filhos & 3 & 6,5 & 18 & 23,7 \\
Genros & 9 & 19,6 & 3 & 3,9 \\
Sobrinhos & 10 & 21,7 & 16 & 21,1 \\
Afilhados & 2 & 4,3 & 6 & 7,9 \\
Cunhados & 1 & 2,2 & 5 & 6,6 \\
Outros & 9 & 19,6 & 10 & 13,2 \\
Total & 46 & $\mathbf{1 0 0 , 0}$ & 76 & $\mathbf{1 0 0 , 0}$ \\
\hline
\end{tabular}

Fontes: ver tabela 1

Analisando com vagar a tabela 5, percebemos o caráter familiar das estratégias de reprodução social. Sobretudo, chama-nos a atenção a importância dos irmãos no encaminhamento dessas estratégias. Eles respondiam sempre por aproximadamente $1 / 4$ de todas as doações. Número significativo e que redefine o próprio mapa de distribuição das riquezas no interior de cada família. E isso porque a maioria dessas doaçôes refere-se a bens herdados ou por herdar.

Muitos dos doadores eram portugueses moradores no Rio de Janeiro, que abriam mão de suas heranças quase sempre em favor de irmãs residentes em Portugal. É o que ocorreu com Manuel Gonçalves da Costa, que doou à sua irmã Ana Maria, moradora no termo da cidade do Porto, seu direito às heranças paterna e materna. ${ }^{56} \mathrm{O}$ mesmo fez o jesuíta Joaquim de Morais em favor de sua irmã Maria Suzana. ${ }^{57}$ Nesses casos, como em outros, fica evidente que a vinda para a América portuguesa, ao mesmo tempo em que representava uma fuga às estreitas possibilidades de ascensão social em Portugal, fazia parte também de uma estratégia familiar que buscava evitar ao máximo a divisão dos bens.

Mas nem sempre era assim. Muitas vezes, doadores e doados moravam próximos, e as doações visavam melhorar a situação dos últimos. Com 
essa intenção, o capitão-mor Luís de Matos Bezerra doou a suas irmãs os rendimentos de uma propriedade rural completa, no valor de 5:600\$000, com casas, senzalas, olaria, bois, fornos, escravos e barcos. ${ }^{58}$

Também José de Jesus, noviço beneditino, preocupou-se em doar para dois irmãos, Maria dos Santos e o padre Francisco de Oliveira Leitão, seus direitos tanto na legítima materna quanto os relativos à herança de seus avós maternos. ${ }^{59} \mathrm{O}$ que é importante nessa escritura é que, além de "corrigir" o caráter igualitário do sistema de herança, concentrando os bens a serem transmitidos em número menor de herdeiros, ela ainda estabelecia uma diferenciação final entre os próprios beneficiados. Para Francisco, José reservou somente dois escravos. O restante dos bens a serem herdados destinava-se exclusivamente a Maria.

Este exemplo fornece-nos uma das chaves para a compreensão do papel dos irmãos nas estratégias familiares. Em praticamente todos os casos analisados, com uma única exceção, os doadores eram homens, geralmente solteiros, e muitas vezes religiosos. Por outro lado, os doados eram quase sempre irmãos ou irmãs casados ou em condições de o serem. Além disso, as doações entre irmãos se davam quase invariavelmente sobre direitos de herança. Ao abrir mão sobre o todo ou parte dos bens a que teria direito, o irmão doador evitava os danos causados pela fragmentação da riqueza deixada pela geração anterior, ao mesmo tempo em que garantia que ela ficasse nas mãos daquela parcela da família que estava em condições de reproduzi-la. Em outras palavras, podemos dizer que o principal eixo dessa estratégia era a diminuição do número de herdeiros efetivos, ou seja, daqueles que chegavam realmente a beneficiar-se da transmissão de riquezas entre geraçóes.

Nesse sentido, fica muito clara a existência de uma hierarquia de prioridades na doação do noviço José. O doador, ao ingressar na Ordem de São Bento, abria mão da possibilidade de produção de sua própria descendência, pelo menos legítima e, além disso, sua sobrevivência passava a estar garantida pela própria Ordem. Esses fatos lhe permitiam o desprendimento necessário para a doação de sua herança aos irmãos. ${ }^{60}$ Francisco, por sua vez, é um raro caso de sacerdote beneficiário de uma doação. Para entender o porquê disso, é necessário ter em conta que se tratava de um padre secular, sendo assim responsável por seu próprio sustento. Não é por 
outra razão que a Igreja obrigava seus lares à formação de patrimônios. $\mathrm{O}$ recebimento de dois escravos, dentro desse quadro, serviria para garantir sua manutenção. Quanto a Maria, as razões para seu privilegiamento são evidentes. Sendo solteira, tal doação significava melhores chances no mercado matrimonial, já que passava a concentrar em si a maior parte dos bens herdados. Por outro lado, era nesse mesmo matrimônio que a família concentrava suas esperanças de reprodução biológica e social.

A mesma estratégia está presente na doação de Luís de Matos Bezerra, citada acima. A propriedade cujos rendimentos ele doou a suas irmãs havia sido comprada apenas nove dias antes a seu avô, o capitão Jerônimo Barbalho Bezerra. A ínfima distância temporal entre os dois fatos não deixa margem a dúvidas quanto às intenções de Bezerra. Ao adquirir uma propriedade familiar, o capitão-mor evitou que ela fosse desmembrada. Dificilmente ela chegaria intacta às suas mãos através da herança. Com seu ato, Bezerra conseguiu ao mesmo tempo conservá-la inteira e no interior do grupo familiar. Ao doá-la a suas irmãs, deixou-as em melhores condições no mercado matrimonial. Repare-se que enquanto o capitão-mor aparentemente permaneceu solteiro ao longo de toda a vida, três das quatro irmãs que lhe são assinaladas casaram-se aproximadamente uma década após a doação. ${ }^{61}$

Mas não é somente nas doações feitas aos membros de sua geração que os irmãos desempenham papel da maior importância. Também podemos perceber sua importância naquelas feitas a sobrinhos. Essas doações seguem, grosso modo, o mesmo padrão das realizadas entre irmãos. A principal diferença é a maior presença de mulheres entre os doadores. Como as mulheres só apareciam desacompanhadas em escrituras se fossem viúvas ou solteiras, temos aí um primeiro forte indício de que as doações entre tios e sobrinhos também visavam freqüentemente redistribuir as riquezas da família para aqueles ramos que haviam se mostrado capazes de garantir sua sobrevivência, evitando ao mesmo tempo a dispersão da fortuna familiar.

São essas as razōes que moveram dona Maria de Marins de Almeida a doar em 1736 uma casa de sobrado a seu sobrinho, Antônio de Escobar. Dona Maria era viúva de Manuel Cordeiro de Sampaio e decidira fazer a doação "por o ter criado e não ter herdeiros forçados" ${ }^{62}$ Situação muito semelhante à vivida por Silvestre da Silva Torres, que, em 1749, resolveu 
doar seus bens para Bernardino de Senna e Silva e José da Silva Torres, ambos filhos de sua irmã Luzia Tereza da Cunha, e igualmente criados por ele. Em troca dos bens, obrigava-os a mantê-lo enquanto fosse vivo e reservava para si um pequeno valor nas propriedades para cumprimento de seus legados. $^{63}$

Poderíamos multiplicar os exemplos, mas o que nos parece mais significativo sublinhar é a importância que tais doações tinham em relação ao total. Tanto no século XVII quanto no XVIII, mais de $40 \%$ do total de doações eram feitas para irmãos ou sobrinhos. A importância desse fato está, como dissemos acima, no privilegiamento que daí decorria de alguns ramos da família em relação a outros, pelo menos no que concerne à distribuição da riqueza familiar acumulada. Esse privilegiamento, ocorrido por meio de doações, permite-nos relativizar ainda mais o papel do dote como elemento compensador da igualdade prevista no sistema português de herança. De fato, fica claro que os grupos familiares podiam lançar mão de uma série de outros mecanismos com essa mesma finalidade.

Da mesma forma, fica evidente a importância, dentro de cada grupo familiar, de uma proporção considerável de solteiros a cada geração. Embora uma análise demográfica mais aprofundada fuja do alcance deste trabalho, parece-nos que a cada ciclo da vida familiar uma parcela ponderável, ainda que minoritária dos seus membros, não se casava nem produzia descendência conhecida. No caso de uma família pertencente à elite agrária, as motivações para isso não seriam de difícil compreensão. A baixa lucratividade de atividade agrícola, o elevado grau de endividamento de seus membros e as dificuldades de divisão dos bens herdados desestimulavam a prática do casamento de todos os quase sempre numerosos filhos.

Contudo, não era somente a elite agrária que se precavia contra as consequiências nefastas de uma excessiva dispersão de sua fortuna. Mesmo famílias de homens de negócio empenhadas na sua ascensão social podiam limitar os enlaces matrimoniais de seus filhos em busca de casamentos mais vantajosos para os beneficiados. O melhor exemplo disso nos é dado por Francisco de Seixas da Fonseca.

Quando de sua morte em 1730, ${ }^{64}$ Francisco de Seixas possuía pelo menos doze filhos vivos. Dos quatro filhos homens, todos eram então solteiros, e pelo menos os três mais velhos morreram nessa condição. ${ }^{65} \mathrm{Um}$ 
deles, João de Seixas da Fonseca, frei beneditino, tornou-se mais tarde bispo titular de Areópolis. Entre as oito mulheres, quatro eram freiras no convento de Nossa Senhora de Chellas, e outras duas estavam aí recolhidas, sem que ainda tivessem definido suas vocaçōes. As duas restantes encontravam-se já casadas. Dona Narcisa Catarina da Fonseca casara no início da década de 1720 com o desembargador Francisco da Cunha Lobo, enquanto sua irmã, dona Francisca de Seixas da Fonseca, casou-se alguns anos depois com o tenente-general das Minas, Bernardo da Silva Ferrão, familiar do Santo Ofício, e fundou com esse matrimônio uma das mais importantes famílias mineiras.

Há uma estratégia clara de ascensão social por parte dessa família, presente não somente nos dois casamentos com funcionários de alto nível do governo lusitano, como também no investimento feito para que João de Seixas se tornasse bispo. Em seu testamento, Francisco de Seixas informa que enviara para o filho, então em Florença, nada menos que 1:000\$000 em letras de câmbio, "para se ordenar de bispo". Ter um filho bispo, sem dúvida, engrandecia toda a família, inclusive porque os benefícios que este alcançasse no serviço ao rei acabariam por reverter a favor desta. Já a presença de um considerável número de freiras entre as irmãs favorecia a concentração dos bens existentes nas mãos de um número menor de filhos.

Por outro lado, é importante lembrar que se os filhos religiosos também representavam um razoável gasto para a família, esses eram sempre menores do que os envolvidos nos casamentos. Para ordenar-se padre secular, por exemplo, era necessário possuir um patrimônio de valor igual ou superior a $400 \$ 000$, de forma a garantir o sustento do religioso. É exatamente essa obrigação que dá origem às "escrituras de patrimônio", em que parentes do ainda candidato a padre doavam-lhe dinheiro ou bens no valor referido. Às vezes os próprios candidatos estabeleciam seus patrimônios sobre bens que já possuíam.

Além disso, ao ordenarem-se esses filhos e filhas diminuíam a demanda tanto por alianças matrimoniais, nem sempre disponíveis com pessoas $\mathrm{da}$ mesma condição, como por dotes. Abrindo mão do estabelecimento de uma descendência, contribuíam para uma menor divisão da riqueza familiar, ao mesmo tempo em que podiam direcionar seus esforços no auxílio a outros parentes, com vistas à ascensão social dos mesmos. 
A escritura que Pedro Dias Paes Leme, "homem fidalgo da casa de sua majestade, guarda-mor das Minas" (e filho de Garcia Rodrigues Pais), fez com seu irmão, Inácio Dias Velho ${ }^{66}$, é bastante ilustrativa dessa estratégia familiar envolvendo a ordenação de alguns de seus membros. Pedro doou, para formar o patrimônio de $400 \$ 000$ de Inácio, parte do valor de uma casa de sobrado. Sobre esse valor, o doador comprometia-se a pagar juros ao irmão. A doação foi feita sob a condição de que após a morte do doado ela retornasse para o doador ou seus herdeiros.

Analisando a importância dessa presença dos solteiros, religiosos ou não, no interior de cada geração, torna-se mais claro o papel desempenhado pelas doações feitas entre irmãos e de tios para sobrinhos. Por trás da aparente naturalidade dos atos, havia um cálculo bastante preciso das necessidades familiares, que presidia a tais ações.

\section{Conclusão}

A análise de algumas das formas de acumulação não-mercantil existentes na sociedade colonial permitiu-nos confirmar o que dissemos no início sobre a inexistência de uma dicotomia entre tais mecanismos de acumulação e a acumulação de capital no sentido mais estrito. Na verdade, ambas as formas de acumulação encontravam-se não só profundamente imbricadas no tecido social como, inclusive, nas estratégias de atuação de um mesmo indivíduo. O exemplo mais claro disso encontramos na atuação dos negociantes. Como foi dito, tal fato não era uma especificidade da América portuguesa, mas uma característica das sociedades de Antigo Regime. Nelas, a esfera econômica encontrava-se inserida na ordem social mais ampla, de que era. Isso equivale a dizer que o estudo da economia em sociedades não-capitalistas não pode ser dissociado de uma análise do conjunto da vida social. Em outras palavras, a economia não pode ser considerada como uma esfera independente, compreensível a partir unicamente de sua organicidade.

Por outro lado, os dados mostram que durante a primeira metade do século XVIII verificou-se um aumento do grau de mercantilização da economia fluminense ou, o que quer dizer o mesmo, da importância da acumulação de capital sobre outras formas de acumulação. Entretanto, em- 
bora reconheçamos essa transformação como uma importante alteração na ordem social, devemos ressaltar que é sobretudo a permanência de certos traços estruturais que se destaca numa análise mais cuidadosa. Ainda que decadentes, as formas de acumulação não-mercantis conservaram um papel de relativo destaque no interior das estratégias de ascensão (ou de manutenção do status) dos diversos grupos da sociedade colonial. Mesmo os homens de negócio, próceres das mudanças em curso, se utilizaram de tais mecanismos em sua busca por enriquecimento e prestígio social. Mais ainda, ao se aproveitarem de seus recursos para se inserirem de forma vantajosa numa ordem social preexistente, tais negociantes terminavam por reforçar as características estruturais da mesma, sobretudo no que se refere às desigualdades sociais. O capital adquire, nesse contexto, um caráter essencialmente conservador e excludente.

\section{Bibliografia}

BACELLAR, Carlos de Almeida P. "Família, herança e poder em São Paulo: 17651822.” São Paulo: CEDHAL, 1991 (mimeografado).

BARRETO, Daniela Santos. "A qualidade do artesão: contribuição ao estudo da estrutura social e mercado interno na cidade do Rio de Janeiro, c.1690-c.1750". Rio de Janeiro: PPGHIS/UFRJ, 2002 (Dissertação de Mestrado).

BARROS, Edval de Souza. "Proprietários rurais e Estado Português em meio ao avanço da fronteira agrária escravista: a capitania do Rio de Janeiro (1763-1808)." Niterói: UFF, 1997 (Dissertação de mestrado).

BLAJ, Ilana. "A trama das tensões: o processo de mercantilização de São Paulo colonial (1681/1721)”. São Paulo, USP, 1995 (Tese de doutorado).

BRAUDEL, Fernand. Civilização material, economia e capitalismo: séculos XVXVIII (Os jogos das trocas). São Paulo: Martins Fontes, 1996.

CARDOSO, Ciro F.S., Escravo ou camponês? O protocampesinato negro nas Américas. São Paulo: Brasiliense, 1987.

CARRARA, Angelo Alves. "Agricultura e pecuária na Capitania de Minas Gerais (1674-1807)." Rio de Janeiro: UFRJ, 1997 (Tese de doutorado).

FARIA, Sheila de Castro. A colônia em movimento: fortuna e família no cotidiano colonial. Rio de Janeiro: Nova Fronteira, 1998. 
FRAGOSO, João e FLORENTINO, Manolo. O arcaísmo como projeto. Rio de Janeiro: Diadorim, 1993.

FRAGOSO, João L. R. "À espera das frotas: hierarquia social e formas de acumulação no Rio de Janeiro, século XVII"; in: Cadernos do LIPHIS, n 1 , Departamento de História da UFRJ, 1995, pp.53-62;

- "A nobreza da República: notas sobre a formação da primeira elite senhorial do Rio de Janeiro (séculos XVI e XVII)". In: Topoi-Revista de História $\mathrm{n}^{\circ}$ 1. Rio de Janeiro: PPGHS/UFRJ, 2000, pp. 45-122.

. "Hierarquias sociais e formas de acumulação no Rio de Janeiro (Brasil), século XVII”. In: Colonial Latin American Review vol. 6, n². Oxford, Carfax, 1997.

FRIDMAN, Fania. Donos do Rio em nome do rei: uma história fundiária da cidade do Rio de Janeiro. Rio de Janeiro: Jorge Zahar/Garamond, 1999.

MARX, Karl. Contribuição para a crítica da economia política. Lisboa: Editorial Estampa, 1971.

. Formaçôes econômicas pré-capitalistas. Rio de Janeiro: Paz e Terra, 1986, 5a. ed.

. O Capital. São Paulo: Bertrand Brasil, 1987, $11^{\mathrm{a}} \mathrm{ed}$.

MATTOS, Hebe. "Trabalho familiar e escravidão: um ensaio de interpretação a partir de inventários 'post-mortem'.” In: Cadernos do ICHF, n.23. Niterói, UFF, agosto de 1990 (mimeografado), pp. 37-47.

. "A cor inexistente: os significados da liberdade no Sudeste Escravista (Brasil: século XIX).” Niterói: UFF, 1993 (Tese de doutorado).

MONTEIRO, Nuno Gonçalo Freitas. O crepúsculo dos grandes: a casa e o patrimônio da aristocracia em Portugal (1750-1832). Lisboa: Imprensa Nacional/Casa da Moeda, s.d..

NAZZARI, Muriel. "Women, the family and property: the decline of the dowry in São Paulo, Brazil (1600-1870)”. Yale Univesity, 1986 (Tese de doutorado).

. "Dotes paulistas: composições e transformações (1600-1870)." In:

Revista Brasileira de História. São Paulo, ANPUH/Marco Zero, vol. 9, no. 17, setembro de 1988/fevereiro de 1989, pp. 87-100.

OSÓRIO, Helen. "Estancieiros, lavradores e comerciantes na constituição da Estremadura portuguesa na América: Rio Grande de São Pedro, 1737-1822.” Niterói: UFF, 1999 (Tese de doutorado). 
RHEINGANTZ, Carlos G. Primeiras famílias do Rio de Janeiro (séculos XVI e XVII). Rio de Janeiro: Livraria Brasiliana Editora, 1965, 4 vols.

SAMPAIO, Antônio Carlos Jucá de. "A pequena produção de alimentos na crise do escravismo: Magé, 1850-1888”. In: Cativeiro e Liberdade, Ano II, Volume 3, 1996, pp. 72-83.

- "Na curva do tempo, na encruzilhada do império: hierarquização social e estratégias de classe na produção de exclusão (Rio de Janeiro, c.1650c. 1750)". Niterói: UFF, 2000 (Tese de doutorado).

SILVA, Francisco C. T. da. "Pecuária, agricultura de alimentos e recursos naturais no Brasil-colônia”. In: SZMRECSÁNYI, Tamás (org.) História econômica do período colonial. São Paulo: Hucitec, 1996, pp. 123-162.

. "A morfologia da escassez: crises de subsistência e política econômica no Brasil Colônia (Salvador e Rio de Janeiro, 1680-1790).” Niterói: UFF, 1990 (Tese de doutorado).

YOUNG, Eric Van. La ciudad y el campo en el México del siglo XVIII: la economía rural de la región de Guadalajara, 1675-1820. México, D. F: Fondo de Cultura Económica, 1989.

\section{Notas}

${ }^{1}$ MARX, Karl. Contribuição para a crítica da economia política. Lisboa: Editorial Estampa, 1971, pp. 134-135.

${ }^{2}$ MARX, Karl. O Capital. São Paulo: Bertrand Brasil, 1987, 11 a ed., p. 167.

${ }^{3}$ Ver, por exemplo: MARX, Karl. Formaçôes econômicas pré-capitalistas. Rio de Janeiro: Paz e Terra, 1986, 5a. ed., pp. 107-111.

${ }^{4}$ BRAUDEL, Fernand. Civilização material, economia e capitalismo: séculos XV-XVIII (Os jogos das trocas). São Paulo: Martins Fontes, 1996, p. 43.

${ }^{5}$ FRAGOSO, João e FLORENTINO, Manolo. O arcaísmo como projeto. Rio de Janeiro: Diadorim, 1993.

${ }^{6}$ Entre outros: MATTOS, Hebe. "Trabalho familiar e escravidão: um ensaio de interpretação a partir de inventários 'post-mortem'.” In: Cadernos do ICHF, n.23. Niterói, UFF, agosto de 1990 (mimeografado), pp. 37-47; CARDOSO, Ciro F.S., Escravo ou camponês? O protocampesinato negro nas Américas. São Paulo: Brasiliense, 1987; FARIA, Sheila de Castro. A colonia em movimento: fortuna e família no cotidiano colonial. Rio de Janeiro: Nova Fronteira, 1998, cap. II; SAMPAIO, Antônio Carlos Jucá de. "A pequena produção de alimentos na crise do escravismo: Magé, 1850-1888". In: Cativeiro e Liberdade, Ano II, Volume 3, 1996, pp. 72-83; BARRETO, Daniela Santos. "A qualidade do arte- 
são: contribuição ao estudo da estrutura social e mercado interno na cidade do Rio de Janeiro, c.1690-c. 1750". Rio de Janeiro: PPGHIS/UFRJ, 2002 (Dissertação de Mestrado).

${ }^{7}$ FRAGOSO, João L. R. "À espera das frotas: hierarquia social e formas de acumulação no Rio de Janeiro, século XVII". In: Cadernos do LIPHIS, n ${ }^{\circ}$, Departamento de História da UFRJ, 1995, pp.53-62; "A nobreza da República: notas sobre a formação da primeira elite senhorial do Rio de Janeiro (séculos XVI e XVII)". In: Topoi Revista de História $\mathrm{n}^{\circ}$ 1. Rio de Janeiro: PPGHS/UFRJ, 2000, pp. 45-122.

${ }^{8}$ Um exemplo interessante éo trabalho de Francisco Carlos Teixeira, que demonstra como o monopólio da terra e, no sentido mais amplo, dos recursos naturais, permitia à elite agrária a obtenção de fontes permanentes de renda. Para uma versão mais recente de seu trabalho, ver: SILVA, Francisco C. T. da. "Pecuária, agricultura de alimentos e recursos naturais no Brasil-colônia”. In: SZMRECSÁNYI, Tamás (org.) História econômica do período colonial. São Paulo: Hucitec, 1996, pp. 123-162.

${ }^{9}$ Para uma análise detalhada da economia fluminense no período, ver: SAMPAIO, Antonio Carlos Jucá de. "Na curva do tempo, na encruzilhada do império: hierarquização social e estratégias de classe na produção de exclusão (Rio de Janeiro, c.1650-c.1750)". Niterói: UFF, 2000 (Tese de doutorado), cap. 1.

${ }^{10}$ Escritura de compra e venda, CSON, L. 62, f. 14, AN (1749). Nessa escritura, José Ferreira de Veras e sua mulher vendem para José Ferreira Sardinha 40 braças de terras no rio Pirassununga, possuídas "mansa e pacificamente, sem contradição de pessoa alguma".

${ }^{11}$ BARROS, Edval de Souza. "Proprietários rurais e Estado Português em meio ao avanço da fronteira agrária escravista: a capitania do Rio de Janeiro (1763-1808)." Niterói: UFF, 1997 (Dissertação de mestrado), pp. 123-134.

${ }^{12}$ MATTOS, Hebe. "A cor inexistente: os significados da liberdade no Sudeste Escravista (Brasil: século XIX).” Niterói: UFF, 1993 (Tese de doutorado), cap. IV.

${ }^{13}$ CARRARA, Angelo Alves. "Agricultura e pecuária na Capitania de Minas Gerais (16741807).” Rio de Janeiro: UFRJ, 1997 (Tese de doutorado), pp. 138-141.

${ }^{14}$ OSÓRIO, Helen. "Estancieiros, lavradores e comerciantes na constituição da Estremadura portuguesa na América: Rio Grande de São Pedro, 1737-1822." Niterói: UFF, 1999 (Tese de doutorado), capítulo 3.

${ }^{15}$ A esse respeito, ver: SAMPAIO, Antonio Carlos Jucá de. Na curva do tempo..., cap. 2. ${ }^{16}$ Segundo as ordenações, as transações por escrituras particulares não podiam exceder o valor de 60\$000: Ordenaçôes Filipinas, Livro Terceiro, Título XXV, \$ 9. Lisboa: Fundação Calouste Gulbenkian, 1985, pp. 609s.

${ }^{17}$ Não devemos, entretanto, passar para o extremo oposto, e considerar que todas as escrituras sem tais dados se refiram a posses. Há casos, por exemplo, de venda de engenhos em que a forma de sua aquisição não é referida. E é evidentemente impossível imaginar que um engenho pudesse ser adquirido por simples posse. Na verdade, fica claro um aumento no século XVIII da preocupação dos envolvidos na transação em esclarecer a origem do 
direito do vendedor sobre a propriedade transacionada. Provavelmente, isso se deveu ao aumento da população da capitania, e conseqüente incremento da ocupação e disputa pelas terras da mesma.

${ }^{18}$ SILVA, Francisco Carlos Teixeira da. "A morfologia da escassez: crises de subsistência e política econômica no Brasil Colônia (Salvador e Rio de Janeiro, 1680-1790).” Niterói: UFF, 1990 (Tese de doutorado), p. 321. Esse processo de monopolização precoce da terra verifica-se também na América Espanhola. Ver, por exemplo, o trabalho de Eric Young sobre a região de Guadalajara: YOUNG, Eric Van. La ciudad y el campo en el México del siglo XVIII: la economía rural de la región de Guadalajara, 1675-1820. México D. F: Fondo de Cultura Económica, 1989, pp. 306-308.

${ }^{19}$ OSÓRIO, Helen. op. cit., pp. 75-83.

${ }^{20}$ Esse processo foi estudado por Francisco Carlos Teixeira: SILVA, Francisco Carlos Teixeira da. A morfologia..., pp. 346-352. Ver também: FRIDMAN, Fania. Donos do Rio em nome do rei: uma história fundiária da cidade do Rio de Janeiro. Rio de Janeiro: Jorge Zahar/ Garamond, 1999, capítulo 4: "Rio de Janeiro Imperial: a propriedade fundiária nas freguesias rurais", pp. 125-232.

${ }^{21}$ Escritura de compra e venda, CSON, L. 58, f. 193, AN (1746).

${ }^{22}$ Escritura de compra e venda, CPON, L. 119, f. 10, AN (1750).

${ }^{23}$ Escritura de compra e venda, CSON, L. 18, f. 121, AN (1713). Na escritura, não fica clara qual era a ligação entre Margarida Ferreira e as vendedoras.

${ }^{24}$ BACELLAR, Carlos de Almeida P. "Família, herança e poder em São Paulo: 1765-1822." São Paulo: CEDHAL, 1991 (mimeografado), capítulo 6, principalmente pp. 59-61.

${ }^{25}$ BACELLAR, Carlos de Almeida P. op. cit., capítulo 7.

${ }^{26}$ Escritura de dote, CPON, L. 44, f. 33, AN (1661).

${ }^{27}$ Escritura de dote, CSON, L. 16, f. 106, AN (1712).

${ }^{28}$ FRAGOSO, João L. R. "Hierarquias sociais e formas de acumulação no Rio de Janeiro (Brasil), século XVII". In: Colonial Latin American Review Vol. 6, $n^{\circ}$ 2. Oxford, Carfax, 1997, p. 154.

${ }^{29}$ SAMPAIO, Antonio Carlos Jucá de. Na curva do tempo..., cap. 3.

${ }^{30}$ A esse respeito, ver: SAMPAIO, Antonio Carlos Jucá de. Na curva do tempo..., capítulos 1 e 4 .

${ }^{31} \mathrm{O}$ mérito, não só pelo pioneirismo como pelas relaçōes que estabeleceu entre as características do dote e as transformaçôes sociais mais amplas ocorridas ao longo do tempo, ainda é de Muriel Nazzari: NAZZARI, Muriel. "Women, the family and property: the decline of the dowry in São Paulo, Brazil (1600-1870)". Yale Univesity, 1986 (Tese de doutorado). Um bom resumo desse trabalho está em: NAZZARI, Muriel. "Dotes paulistas: composiçōes e transformaçōes (1600-1870).” In: Revista Brasileira de História. São Paulo, ANPUH/Marco Zero, vol. 9, no. 17, setembro de 1988/fevereiro de 1989, pp. $87-100$. 
32 Naturalmente, poderíamos ter feito a comparação com o total de vendas urbanas, o total de todas as vendas, o total das escrituras, etc. O que buscamos com essa comparação é simplesmente demonstrar que as escrituras de dote tornaram-se menos comuns nos setecentos.

${ }^{33}$ NAZZARI, Muriel. Dotes..., pp. 98s.

${ }^{34}$ Idem, Ibidem.

${ }^{35}$ Em 1674, Dona Isabel de Azevedo, viúva do capitão Inácio Cardoso, dota seu genro Diogo de Montarroio de Lucena com metade de um engenho. A outra metade já pertencia a seu outro genro, Agostinho de Paredes: Escritura de dote, CPON, L. 53, f. 75v, AN (1674). Ver também: Escritura de dote, CSON, L. 17, f. 139v, AN (1712).

${ }^{36} \mathrm{O}$ texto abaixo é baseado em: NAZZARI, Muriel. Dotes..., pp. 87-95.

${ }^{37}$ Idem, Ibidem., p. 94.

${ }^{38}$ Sobre a crescente mercantilização da economia paulista setecentista, ver: BLAJ, Ilana. "A trama das tensões: o processo de mercantilização de São Paulo colonial (1681/1721)". São Paulo, USP, 1995 (Tese de doutorado).

${ }^{39}$ É claro que isso não significava que uma casa doada, por exemplo, não seria utilizada pelo futuro casal como local de trabalho, até porque moradia e trabalho davam-se quase sempre no mesmo espaço. Entretanto, o fato de os instrumentos e demais bens que fariam parte de tal trabalho não constarem dos dotes demonstra que estes não se destinavam a garantir o sustento continuado do novo casal.

40 "Partidos de canas" eram propriedades agrícolas produtoras de cana-de-açúcar e situadas dentro de engenhos de terceiros. Para uma análise detalhada do agro fluminense no período, ver: SAMPAIO, Antonio Carlos Jucá de. Na curva do tempo..., cap. 2.

${ }^{41}$ Escritura de dote, CPON, L. 44, f. 203v, AN.

${ }^{42}$ Escritura de dote, CPON, L. 117, f. 126, AN.

${ }^{43}$ Escritura de dote, CPON, Códice 42-3-56, f. 60, AGCRJ (1663).

${ }^{44}$ Uma análise das informações dadas por Rheingantz, cruzadas com outras fontes, mostra que havia um claro padrão de transferência da propriedade do engenho da Lagoa para os genros. Quem herda o engenho de Teles Barreto é seu genro, o capitão Rodrigo de Freitas, que acabou dando nome à lagoa em que o mesmo se localizava: RHEINGANTZ, Carlos G. Primeiras famílias do Rio de Janeiro (séculos XVI e XVII). Rio de Janeiro: Livraria Brasiliana Editora, 1965, Vol. II, p. 6.

${ }^{45}$ Escritura de dote, CPON, L. 48, f. 90, AN (1668).

${ }^{46}$ Escritura de dote, CPON, Códice 42-4-91, f. av., AGCRJ (1697).

${ }^{47}$ Escritura de dote, CPON, L. 57, f. 197, AN (1745).

${ }^{48}$ Escritura de dote, CPON, L. 109, f. 243v, AN (1744).

49 Também entre os "Grandes" de Portugal o dote perdeu a função de instrumento de acumulação de bens patrimoniais a partir da segunda metade do século XVII, além de 
geralmente não incluir bens de raiz. A razão para essa mudança foi o encerramento desse grupo a partir desse período, o que eliminou a competição no mercado matrimonial: MONTEIRO, Nuno Gonçalo Freitas. O crepúsculo dos grandes: a casa e o patrimônio da aristocracia em Portugal (1750-1832). Lisboa: Imprensa Nacional/Casa da Moeda, s.d., capítulo 5 .

${ }^{50}$ Bom exemplo do que estamos afirmando é o próprio capitão João Barbosa de Sá Freire, citado acima. Três anos após o seu casamento, ele comprou um engenho de seu avô, o coronel Francisco de Macedo Freire. O que mostra que a reprodução da elite agrária não passava, ao menos de forma direta, pelos dotes concedidos. Ver: Escritura de compra e venda, CSON, L. 60, f. 29v (1748).

${ }^{51} \mathrm{O}$ fato de que, mesmo com o aumento da participação das casas nos dotes, estes tenham visto diminuir sua participação entre as formas de aquisição das propriedades urbanas, evidencia mais uma vez sua decadência como instrumento de transmissão de riqueza na sociedade fluminense setecentista.

52 Escritura de dote, CPON, L. 118, f. 87v, AN (1749).

${ }^{53}$ Escritura de dote, CPON, L. 119, f. 141v, AN (1750).

${ }^{54}$ Escritura de doação, CPON, L. 47, f. 80v, AN (1666).

55 É o próprio frei quem traz 19 escravos de Angola. Desses, 4 morreram na viagem e 5 foram vendidos para pagar o frete. Como os demais 10 escravos são doados para as sobrinhas, a ajuda a estas parece ser o motivo dessa participação do doador no tráfico negreiro. Ver: Escritura de doação, CPON, L. 54, f. 241v, AN (1680).

${ }^{56}$ Escritura de doação, CSON, L. 44, f. 4v, AN (1733).

${ }^{57}$ Escritura de doação, CSON, L. 51, f. 37, AN (1739).

${ }^{58}$ Escritura de doação, CSON, L. 19, f. 76v, AN (1713). A propriedade seria administrada por seu pai, o capitão João Batista de Matos, em benefício de suas irmãs.

${ }^{59}$ Escritura de doação. CSON, L. 40, f. 238v, AN (1730). É importante ressaltar que o pai de doador e doados, o capitão Francisco de Oliveira Leitão, ainda encontrava-se vivo quando da feitura da escritura.

${ }^{60}$ Esse desprendimento não deve, entretanto, ser exagerado. Não significa que José tenha aberto mão de todos os seus bens. Os dois escravos que doa para Francisco, por exemplo, são filhos de sua escrava Rosa, a qual permanece com José.

${ }^{61}$ RHEINGANTZ, Carlos G. Primeiras famílias do Rio de Janeiro (séculos XVI e XVII). Rio de Janeiro: Livraria Brasiliana Editora, 1965, vol. II, pp. $571 \mathrm{s.}$

${ }^{62}$ Escritura de doação, CSON, L. 47, f. 72v, AN.

${ }^{63}$ Ver: Escritura de doação, CPON, L.118, f. 52v, AN; Escritura de doação, CPON, L.118, f. 95, AN.

${ }^{64}$ As informações aqui apresentadas são retiradas de: RHEINGANTZ, Carlos G. Primeiras famílias do Rio de Janeiro (séculos XVI e XVII). Rio de Janeiro: Livraria Brasiliana Edi- 
tora, 1965, Vol. 3, fascículo $3^{\circ}$, pp. 144s; AMSB, doc. 812 - Testamento de Francisco de Seixas da Fonseca e 824 - Inventário de Francisco de Seixas da Fonseca.

${ }^{65}$ Somente 1, Roque de Seixas da Fonseca, ainda era menor quando da morte do pai.

${ }^{66}$ Escritura de patrimônio. CSON, L. 58, f. 29, AN (1745).

\section{Resumo}

Este artigo procura analisar as formas não-mercantis de acumulação existentes na sociedade colonial fluminense entre 1650 e 1750. Nosso objetivo é tanto o de conhecer as formas concretas assumidas por esse tipo de acumulação quanto aquilatar sua importância relativa, em comparação com a acumulação de capital em sentido estrito. Esse periodo é marcado por intensas transformaçôes econômico-sociais na capitania, fruto tanto de sua evolução interna quanto de fenômenos que podemos considerar até certo ponto externos, como a descoberta de ouro e a conseqüente colonização do interior da América portuguesa. Assim, buscamos perceber igualmente como tão importantes transformaçôes influenciaram nas estratégias de acumulação dos diversos grupos sociais locais no periodo.

Palavras-chave: história socioeconômica; sociedade colonial; estratégias sociais.

\section{Abstract}

This article analyses the non-mercantiles ways of accumulation in the Fluminense colonial society of the period between 1650 and 1750. Its objective is to explore the specific aspects showed by this kind of accumulation and to analyse its importance in comparison with accumulation of capital stricto sensu. The period studied is marked by intense social and economic transformations, resulting both from internal evolutions and what could be considered an external phenomenon, the discovery of gold in Minas Gerais and the subsequent colonization of the interior of Portuguese America. Our objective is to show how these transformations influenced the strategies of accumulation adopted by diverse local social groups.

Key-words: Socio-economic history; colonial society; social stratagies. 